\title{
PEMANFAATAN SOSIAL MEDIA SEBAGAI STRATEGI PROMOSI BAGI SUSTAINABILITY BISNIS UMKM
}

\author{
${ }^{1}$ Silvester Dian Handy Permana, ${ }^{2}$ Maya Cendana \\ ${ }^{1,2)}$ Universitas Trilogi, Jakarta, Indonesia \\ Email: ${ }^{1}$ handy@trilogi.ac.id, ${ }^{2}$ maya.cendana@trilogi.ac.id
}

\begin{abstract}
The financial climate in Indonesia is now growing and developing especially for MSME businesses. In moving the small and medium economy, many Indonesians become small traders who market products to others. They seek their fortune to become traders for profit. Some traders sell their wares in stalls and others that sell around. Many of Indonesian traders have not used information technology to sell. While information technology can be utilized only from one hand through social media. Social media like Facebook Instagram and Twitter can be used to sell merchandise. This service activity provides complete information on social media for MSME business traders or entrepreneurs. This activity will also provide a strategy to win the social media market. This activity is expected to help people who are doing MSME business to sell their business online through social media.

Keywords: Utilization of Information Technology, e-business Strategy, Social Media, E-Marketing Strategy
\end{abstract}

\begin{abstract}
Abstrak. Iklim perekonomian di Indonesia sekarang sedang tumbuh dan berkembang terutama untuk bisnis UMKM. Di dalam menggerakkan perekonomian mikro kecil dan menengah, Banyak masyarakat Indonesia menjadi pedagang kecil yang memasarkan suatu produk kepada orang lain. Mereka mencoba peruntungan nasib menjadi pedagang untuk mencari keuntungan. Beberapa pedagang menjual dagangannya di lapak dan lainnya ada yang menjual keliling. Banyak dari pedagang Indonesia belum memanfaatkan teknologi informasi untuk berjualan. Padahal teknologi informasi dapat dimanfaatkan hanya dari genggaman tangan salah satunya melalui media sosial. Media sosial seperti Facebook Instagram dan Twitter dapat digunakan untuk menjual barang dagangannya. Kegiatan pengabdian ini memberikan informasi secara menyeluruh mengenai media sosial untuk para pedagang atau pegiat bisnis UMKM. Kegiatan ini akan memberikan juga strategi untuk memenangkan pangsa pasar dalam media sosial. Kegiatan ini diharapkan dapat membantu masyarakat yang berbisnis UMKM untuk menjual bisnisnya secara online melalui media sosial.
\end{abstract}

Kata Kunci: Pemanfaatan Teknologi Informasi, Strategi e-bisnis, Media Sosial, EMarketing Strategy.

\section{Pendahuluan}

Iklim perekonomian Indonesia sekarang tumbuh di angka 5,1\%. Banyak masyarakat Indonesia menjadi pedagang dalam usaha skala mikro kecil dan menengah (UMKM). Para pedagang besar membuka jalan bagi para pedagang kecil untuk berjualan dengan tidak mencari keuntungan yang banyak sehingga para pedagang kecil 
mendapatkan laba dengan berjualan barang dagangannya. Hal seperti ini banyak dimanfaatkan oleh para pedagang kecil untuk berjualan barang dari para pedagang besar. Dari segi penjualannya pun beragam ada yang mulai memasarkan dengan cara berkeliling maupun dengan cara membuka lapak di tempat lain namun masih sedikit yang memanfaatkan media sosial atau teknologi informasi dalam berdagang.(Bin Hasri, Sigit Santoso, 2014)

Jumlah pengguna media sosial di Indonesia hampir mencapai angka 100 juta orang. Dengan keunggulan teknologi informasi ini harusnya dapat dimanfaatkan oleh para pelaku bisnis UMKM agar dapat meraih keuntungan yang optimal. Menurut data penelitian dari we are social, jumlah penduduk Indonesia yang memanfaatkan media sosial Facebook sebanyak 80 juta, Twitter sebanyak 38 juta dan Instagram sebanyak 52 juta. Jika media sosial dimanfaatkan secara optimal maka hal ini dapat membantu bisnis UMKM dalam memiliki pelanggan baru (Pratiwi \& Bungin. 2018). Dari setiap sosial media mempunyai layanan dan fitur masing-masing yang berbeda. Dengan adanya fitur dan layanan masing-masing yang berbeda tentunya dibutuhkan strategi-strategi untuk memasarkan produk yang kita jual dan memenangkan kompetisi market di sana. Hal ini dilakukan karena sudah ada pengusaha yang memanfaatkan media sosial untuk mempromosikan dagangannya. Pada kegiatan ini sebelum memberikan pembinaan kepada bisnis UMKM yang sedang berkembang telah dilakukan penelitian oleh Permana tahun 2016 mengenai pemanfaatan sosial media sebagai strategi penunjang bisnis ecommerce (Permana, 2016).

Penelitian tersebut dapat membantu kegiatan ini untuk mencari strategi dalam pemenangan kompetisi di market media sosial. Selain itu sebelum kegiatan pengabdian ini dimulai, pada tahap penyusunan model dan strategi, kami juga mempelajari mengenai user behavior yang ada di dalam media sosial. User behavior ini mempelajari pola berpikir dan pola berinteraksi antara satu orang dengan lainnya di dalam media sosial. Diharapkan dengan mempelajari user behavior dapat menentukan strategi apa yang dibutuhkan oleh para pelaku bisnis UMKM (Waluyo \& Budiarsi, 2018).

\section{Solusi Permasalahan}

Permasalahan yang dapat diambil dari para pelaku bisnis UMKM adalah strategi pemasaran yang kurang memanfaatkan media sosial. Kurangnya segi pemasaran dapat mengakibatkan turunnya sustainability dari para pelaku bisnis UMKM. Keberlangsungan bisnis UMKM bersandar pada banyaknya transaksi penjualan maupun pembelian yang ada. Setiap hari mereka mempunyai target tertentu dalam penjualannya untuk dapat meningkatkan perekonomian mereka. Penjualan secara konvensional berupa berjualan dengan lapak atau berkeliling belum cukup untuk menambah perekonomian bisnis UMKM. Peran teknologi informasi melalui media sosial sangat dibutuhkan untuk keberlangsungan bisnis UMKM.

Media sosial dalam teknologi informasi semakin banyak macamnya. Ada yang berbasis forum, ada yang berbasis chat dan ada yang berbasis timeline. Berdasarkan jumlah masyarakat yang aktif dalam media sosial, didapatkan tiga peringkat teratas dalam penggunaan media sosial. Ketiga media sosial tersebut adalah Facebook Twitter dan Instagram. Media sosial tersebut adalah media sosial dominan yang dipakai oleh masyarakat Indonesia dan ketiga sosial tersebut menjadi topik utama dalam kegiatan pengabdian ini (Pratiwi \& Bungin, 2018). 
Facebook adalah media sosial paling populer di Indonesia di mana jumlah penduduk Indonesia yang memanfaatkan Facebook sebanyak 80 juta jiwa. Facebook didirikan di Amerika Serikat oleh Mark Zuckerberg. Facebook sendiri mempunyai anggota aktif lebih dari 2.17 miliar orang. Masyarakat Indonesia yang menggunakan Facebook didominasi oleh kalangan muda yang memanfaatkan smartphone untuk mengakses Facebook. Facebook mempunyai berbagai fitur di dalamnya di mana para pebisnis UMKM dapat memanfaatkan fitur tersebut untuk memasarkan barang dagangannya. Facebook memiliki Group jual beli dan fanspage yang digunakan untuk berjualan. Grup jual beli suatu barang pastinya sudah banyak tetapi harus dibutuhkan klasifikasi yang mendalam dan strategi dalam memposting setiap item penjualannya. Dalam menjual jasa dan barang secara fisik itu berbeda cara pemasarannya melalui media sosial secara umumnya. Fanspage di Facebook dapat digunakan untuk membangun toko online atau katalog yang merepresentasikan bisnis UMKM. Penggunaan fanpage Facebook ini juga mempunyai cara khusus untuk menjangkau lebih banyak orang agar mereka mengetahui produk knowledge kita. (Bayer, Ellison, Schoenebeck, Brady, \& Falk, 2018)

Berbeda dengan Facebook, media sosial Twitter memiliki sudut pandang yang lain. Twitter memiliki karakter yang terbatas untuk setiap postingannya. Keterbatasan karakter di Twitter ini membuat para pelaku bisnis juga harus memberikan kata yang tepat untuk setiap postingannya. Media sosial Twitter juga memperkenalkan trending topik di mana hal tersebut adalah topik yang lagi banyak dibicarakan di media sosial Twitter. Jika barang dagangan yang dijual oleh para pebisnis UMKM masuk dalam trending topik pastinya bisnis UMKM maju dengan pesat. Hal ini dikarenakan banyaknya interaksi pengguna Twitter yang sedang membicarakan bisnis UMKM tersebut. Para pengguna Twitter biasanya ingin tahu dan mencoba produk yang sedang menjadi trending topic tersebut. Media sosial Twitter juga mempunyai fitur near me di mana fitur tersebut dapat melihat barang dagangan apa yang sedang dibicarakan di wilayah atau lokasi sekitar para pembisnis UMKM. Dengan pemanfaatan fitur tersebut tentunya para pegiat bisnis UMKM dapat mengambil kesempatan dalam berjualan barang dagangannya ( $\mathrm{Li}$, Hughes, \& Howe, 2018).

Media sosial Instagram memiliki fitur yang berbeda pula dari media sosial Facebook dan Twitter di atas. Instagram mengenalkan foto yang menjadi pokok bahasan utama di dalam interaksi di media sosialnya. Setiap foto yang di publikasikan di Instagram memiliki caption atau keterangan foto yang dapat mendeskripsikan foto yang terposting. Hal ini tentunya sangat bermanfaat untuk para pebisnis UMKM dalam memasarkan produk dagangannya. Instagram juga memiliki fitur hashtag di mana fitur tersebut dapat merangkum seluruh gambar yang berada di dalam kategori hastag tersebut. Hasil tersebut memudahkan orang lain untuk mencari suatu benda atau barang yang sesuai dengan kategori hastag tersebut hal ini dapat dimanfaatkan para pembisnis UMKM untuk memasarkan dagangannya yang sesuai dengan suatu hashtag tertentu. Coverage dari Instagram adalah follower gimana jumlah follower yang banyak dapat menyebabkan banyak pola interaksi yang ada di media sosial tersebut. Banyaknya foto dan hastag serta caption yang sesuai dengan foto tersebut dapat meningkatkan jumlah follower yang ada sehingga jumlah jangkauannya dapat meningkat (Meier \& Schäfer, 2018). 
Kegiatan ini mengharapkan seluruh pembisnis UMKM yang terlibat dapat memanfaatkan media sosial dengan optimal. Dalam mengoptimalkan media sosial tentu saja memiliki strategi dalam memenangkan pangsa pasar di media sosial tersebut. Diharapkan dengan adanya kegiatan pengabdian ini dapat membantu para pembisnis UMKM dalam menjaga keberlangsungan bisnisnya.

\section{Metode Penelitian}

Kegiatan yang diusulkan dalam pelaksanaan pengabdian ini adalah

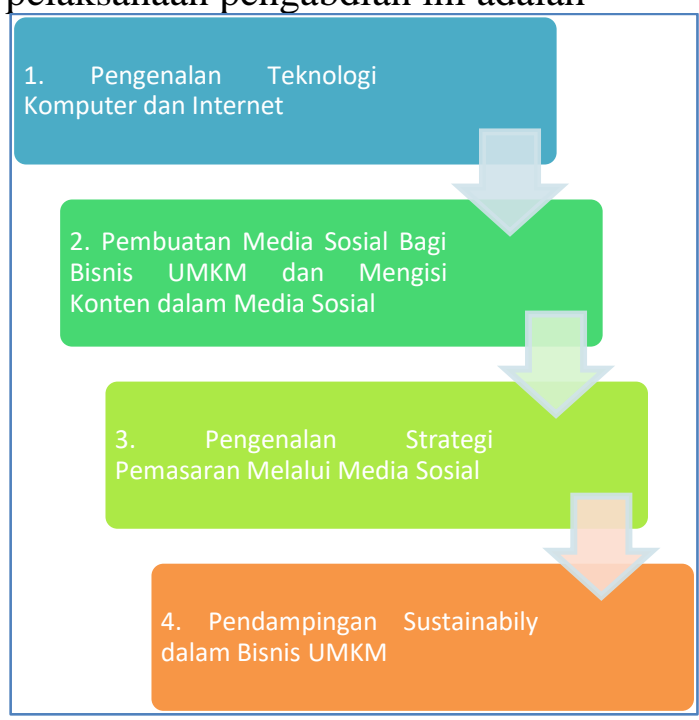

Gambar 1 Alur proses pelaksanaan Kegiatan Pengabdian

Kegiatan pengabdian ini mempunyai 4 buah materi yang akan disampaikan yang terdapat pada Gambar 1. Kegiatan ini dibagi menjadi 4 buah materi agar dalam pemanfaatan teknologi informasi dapat diterima secara menyeluruh. (1) Pengenalan Teknologi Komputer dan Internet. Para UMKM diharapkan mampu untuk mengoperasionalkan teknologi komputer dan dapat mengenal mengenai internet lebih dalam. Pemberian materi mengenai internet ini diarahkan untuk menjadi pendukung ekonomi digital. Ekonomi digital dengan memanfaatan internet pada zaman ini juga akan dijelaskan pada sesi ini. Sesi yang pertama dan kedua ini akan dilakukan pada hari yang bersamaan. Pembuatan Media Sosial Bagi Bisnis UMKM dan Mengisi Konten dalam Media Sosial. Dalam pembuatan media sosial ini akan dipandu bagaimana cara membuat akun media sosial bagi bisnis UMKM karena akun bisnis berbeda dengan akun pribadi dalam media sosial. Pengisian kontennya juga perlu didampingi agar dapat memanfaatkan berbagai fitur dalam konten media sosial. (3) Pengenalan Strategi Pemasaran Melalui Media Sosial. Strategi dibutuhkan dalam pemasaran. Strategi dalam media sosial ini berperan agar barang dagangan maupun jasa yang ditawarkan para pebisnis UMKM mendapat jangkauan yang meluas kepada masyarakat. Selain itu, strategi ini dibutuhkan dalam pemenangan mangsa pasar di media sosial. (4) Pendampingan Sustainabily dalam Bisnis UMKM. Strategi dalam media sosialpun belum cukup karena diperlukan pendampingan agar bisnis berlanjut secara simultan. Dalam pendampingan ini akan dijelaskan mengenai maintenance strategi dalam bisnis UMKM. Perawatan dan Pengembangan strategi sangat dibutuhkan agar para pegiat bisnis UMKM dapat berlangsung lama dalam berbisnis.

\section{Hasil dan Pembahasan}

Kegiatan pengabdian ini dijadwalkan dan dilaksanakan dalam dua kali pertemuan dengan peserta yang berbeda. Pertemuan ini dilaksanakan selama 2 jam dengan pembagian waktu 30 menit setiap materinya. Seluruh peserta diharapkan membawa alat komunikasi berupa smartphone dan mempunyai koneksi internet serta sudah mempunyai email pribadi yang terdaftar di smartphone. 
Pertemuan

pertama

menghadirkan ibu-ibu PKK dari daerah Kelurahan Tomang Kecamatan Grogol Petamburan Jakarta Barat. Kegiatan ini berlangsung pada tanggal 10 Desember 2018. Peserta kegiatan merupakan ibu rumah tangga yang ingin mempunyai pekerjaan sampingan yaitu berjualan secara online. Kegiatan ini dilaksanakan di salah satu rumah peserta acara ini. Pertemuan ini dihadiri oleh kurang lebih 10 peserta. Dokumentasi kegiatan pada pertemuan pertama ini dapat dilihat pada gambar 2 dan gambar 3.

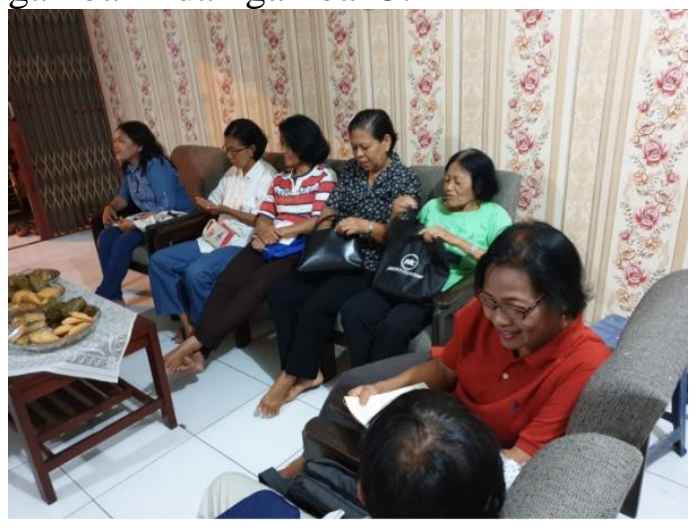

Gambar 2. Dokumentasi Pelatihan Pertama

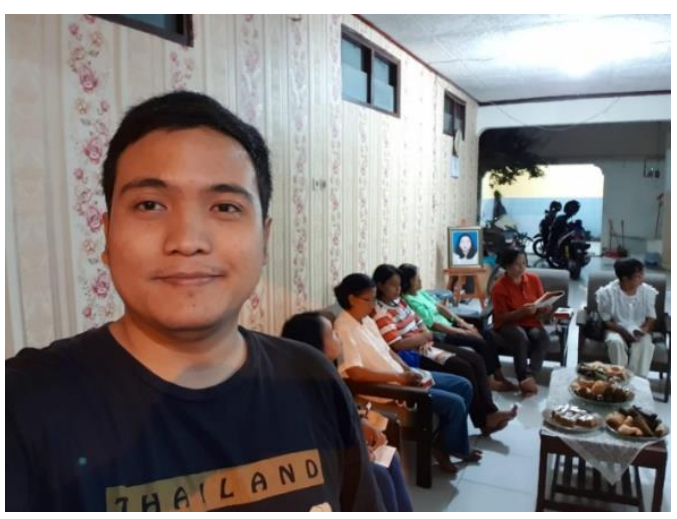

Gambar 3. Dokumentasi Pelatihan Pertama

Dalam pertemuan yang pertama ini, pemahaman dari pesertanya banyak yang belum mengenal internet secara mendalam. Ibu-ibu ini hanya mengenal koneksi internet untuk kebutuhan komunikasi seperti WhatsApp. Hal ini cukup untuk menjadi dasar pengenalan teknologi informasi yang dapat digunakan untuk mengembangkan bisnis UMKM. Dalam pembahasan di awal kegiatan pengabdian ini para peserta masih belum mempunyai gambaran bisnis apa yang akan ditekuni. Kami membantu para peserta untuk mendapatkan ide dalam pembuatan bisnis yang baru. Kami menawarkan opsi yaitu menjadi reseller pakaian, kacamata, produk makanan beku, hingga makanan ringan. Sesi ini menghasilkan 4 hingga 5 usaha yang baru dibentuk. Beberapa peserta yang mengikuti kegiatan ini masih belum berani komitmen untuk berjualan secara online. Setelah mengetahui dan memahami produk yang akan dijual nantinya berserta dimana akan membeli produk tersebut, acara ini berpindah sesi ke pengenalan teknologi informasi dan pembuatan akun sosial media. Sesi ini mewajibkan peserta yang telah mempunyai ide usaha baru untuk membuat akun sosial media dalam Facebook Twitter dan Instagram. Setelah mempunyai akun dari sosial media tersebut kegiatan ini berjalan dengan mengisi konten dari produk yang dijual ke ke sosial media tersebut. Dalam sesi ini juga diajarkan mengenai proses pengunggahan foto ke media sosial berserta pemanfaatan fasilitas-fasilitas dalam media sosial seperti fitur hastag, grup, follower, dsb. Sesi terakhir pada kegiatan ini adalah mengoptimalkan sosial media agar dapat mendatangkan keuntungan bagi para peserta kegiatan. Proses dalam mendatangkan keuntungan ini adalah memberikan tips dan cara khusus agar barang dagangan dapat laku terjual. Hasil yang didapatkan dari pelatihan ini adalah pembuatan usaha baru yang mudah untuk ditekuni para peserta dan pemanfaatan sosial media secara optimal untuk mendatangkan keuntungan.

Pertemuan kedua pada kegiatan ini mempunyai peserta dengan latar 
belakang sudah memiliki usaha sebelumnya. Mereka memanfaatkan sosial media untuk menjajakan barang dagangannya. Namun setelah adanya wawancara singkat mengenai penggunaan sosial media yang telah dilakukan selama ini, masih ada berapa hal yang belum mereka diketahui dan belum dioptimalkan. Pertemuan kedua ini kami diundang oleh Flavia Eyewear dan NG Beauty. Dalam kesempatan ini kami memaparkan optimalisasi sosial media untuk mendatangkan keuntungan bagi para pebisnis UMKM. Dokumentasi kegiatan pada pertemuan kedua ini dapat dilihat di gambar 4 dan gambar 5

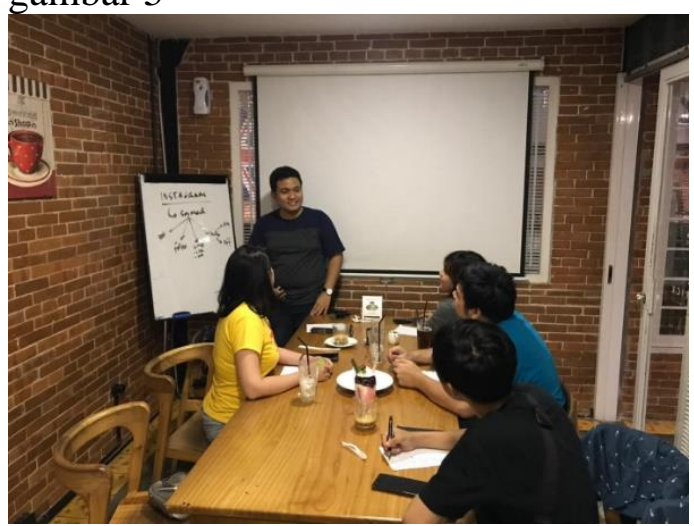

Gambar 4. Dokumentasi Pelatihan Kedua

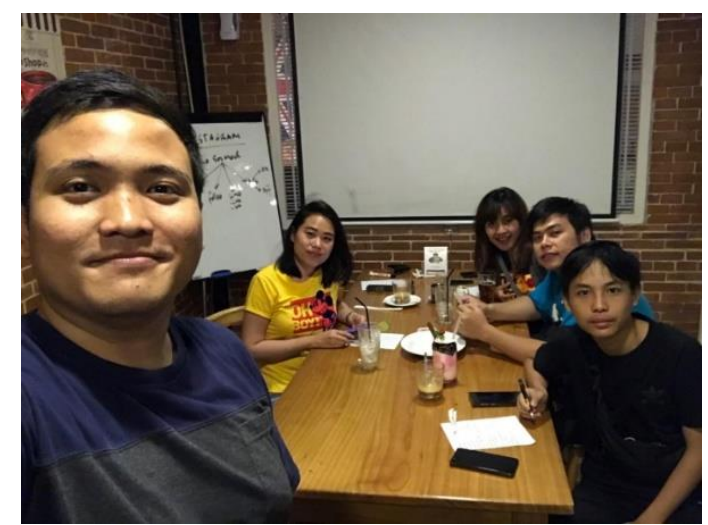

Gambar 5. Dokumentasi Pelatihan Kedua

\footnotetext{
Pertemuan kedua ini diawali dengan sesi wawancara singkat mengenai sosial media apa saja yang telah dipakai untuk usaha dagang yang
}

selama ini dilakukan. Hasil dari wawancara singkat ini didapatkan bahwa mereka telah menggunakan sosial media Instagram dan menggunakan marketplace Shopee. Mereka menggunakan sosial media Instagram bermula dari awal mereka berjualan. Mereka juga sudah menggunakan beberapa fitur Instagram seperti hashtag dan follower. Namun, mereka belum membentuk komunitas untuk para pedagang agar saling mengikuti toko online sehingga dapat meningkatkan kepercayaan dari customer. Selain itu yang dapat dikembangkan dari Instagram untuk peserta pada kegiatan ini adalah akun buzzer yang dapat mendongkrak jumlah pengikut atau follower yang berada di Instagram. Tentunya akun Blazer yang disarankan ini berasal dari selebriti Instagram atau selebgram agar dapat meningkatkan jumlah pengikut yang asli. Hal ini disarankan karena banyak akun booster yang biasa dibeli di sosial media yang dapat meningkatkan jumlah follower namun kebanyakan akun palsu atau yang sering disebut akun bot. Hal ini disampaikan karena berapa toko online yang sudah menggunakan jasa akun booster ini mendapatkan jumlah follower yang banyak sehingga dapat mendongkrak jumlah transaksi di dalam toko onlinenya. Hasil dari kegiatan pengabdian pada masyarakat yang kedua ini diharapkan dapat meningkatkan transaksi dalam toko online kedepannya.

\section{Kesimpulan}

Kesimpulan yang dapat ditarik dari kedua pertemuan ini adalah bahwasanya Teknologi informasi berupa sosial media dapat menjadi media untuk membuat bisnis baru dengan cara berjualan online serta Optimalisasi semua fitur di dalam sosial media beserta mencoba segala peluang dalam mempromosikan toko online dapat meningkatkan jumlah transaksi 
dikemudian hari. Selain itu Keberlangsungan usaha bisnis UMKM tergantung pada kestabilan dan peningkatan jumlah transaksi yang ada. Oleh maka itu diperlukan promosi baik melalui di sosial media maupun non sosial media untuk meningkatkan jumlah transaksi.

\section{Ucapan Terima Kasih}

Kami berterima kasih kepada Universitas Trilogi yang telah memberikan kesempatan dan dukungan bagi kami dalam melakukan acara atau kegiatan pengabdian ini. Kami juga berterima kasih kepada peserta kegiatan ini yang telah mengundang kami agar dapat berbagi ilmu pengetahuan mengenai sosial media.

\section{Daftar Pustaka}

Bayer, J., Ellison, N., Schoenebeck, S., Brady, E., \& Falk, E. B. (2018). Facebook in context(s): Measuring emotional responses across time and space. New Media and Society, 20(3),1047-1067. https://doi.org/ $0.117 / 1461444816681522$

Bin Hasri, Sigit Santoso, D. S. T. (2014). Analisis Pengembangan Usaha Mikro Kecil Menengah Untuk Meningkatkan Pertumbuhan Ekonomi Sebagai Upaya Pengentasan Kemiskinan Dan Pengangguran Daerah Di Kabupaten Ngawi. Jurnal Pendidikan Insan Mandiri, 2(1).

Li, Y., Hughes, A. L., \& Howe, P. D. (2018). Communicating Crisis with Persuasion: Examining Official Twitter Messages on Heat Hazards. Proceedings of the 15th International Conference on Information Systems for Crisis Response and Management ISCRAM2018, (May 2018).
Meier, A., \& Schäfer, S. (2018). The Positive Side of Social Comparison on Social Network Sites: How Envy Can Drive Inspiration on Instagram. Cyberpsychology, Behavior, and Social Networking, 21(7), 411-417. https://doi.org/10.1089/cyber.2017.0 708

Permana, S. D. H. (2016). E-Marketing Strategy In Game Industry With Social Media Using E-Business Model, 258-263.

Pratiwi, T. A., \& Bungin, H. M. B. (n.d.). Kebebasan Berpendapat Melalui Facebook Dan Twitter :

Waluyo, A. J., \& Budiarsi, S. Y. (n.d.). Sistem Informasi Keuangan Untuk Meningkatkan Kinerja Umkm. Kompetensi Trunojoyo. 